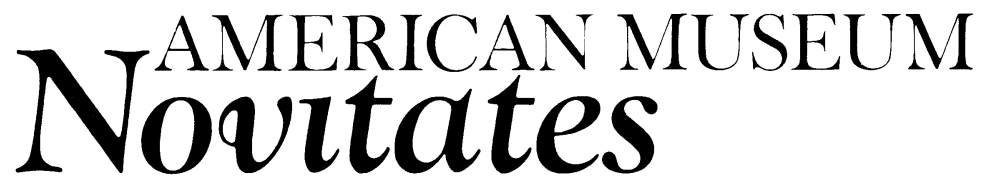

PUBLISHED BY THE AMERICAN MUSEUM OF NATURAL HISTORY CENTRAL PARK WEST AT 79TH STREET, NEW YORK, NY 10024 Number 3452, 16 pp., 4 figures

August 23, 2004

\title{
The Genus Thoron Haliday (Hymenoptera: Scelionidae), Egg-Parasitoids of Waterscorpions (Hemiptera: Nepidae), with Key to World Species
}

\author{
NORMAN F. JOHNSON ${ }^{1}$ AND LUBOMIR MASNER ${ }^{2}$
}

\begin{abstract}
The world fauna of the genus Thoron is revised. The genus is described and Neothoron Masner is treated as a junior synonym (new synonymy). Relationships with Elgonia Risbec and other Scelionidae are discussed and a key to world species is presented. Six new species are described: $T$. dayi, new species (Indonesia), $T$. dux, new species (Bolivia, Venezuela), $T$. garciai, new species (Venezuela, Bolivia), T. rex, new species (Bolivia), Thoron rivalis, new species (Brazil, Panama), and T. spinifer, new species (Ecuador). Thoron metallicus Haliday (Holarctic), T. longicornis Masner and Huggert (USA), and T. lautus (Masner), new combination (Ecuador, Bolivia) are redescribed; the female of T. lautus and the male of T. longicornis are described and keyed for the first time. Thoron gibbus Ruthe is treated as a junior synonym of T. metallicus (new synonymy). Species of Thoron are only known to parasitize the eggs of Nepidae (Hemiptera: Heteroptera) with rearings from Nepa Linnaeus and association with Curicta Stål; apparently the genus Ranatra Fabricius is not a host.
\end{abstract}

\section{INTRODUCTION}

The members of several superfamilies of parasitic Hymenoptera are known to search for hosts in aquatic habitats. A number of genera of the family Scelionidae (Platygastroidea) are also associated with such habi- tats, with the females searching for hosts near or even under water. Where known, these species parasitize the eggs of aquatic Heteroptera and Odonata, with documented rearing records of hosts in the families Gerridae, Nepidae, and Aeshnidae. The genus Thoron

\footnotetext{
${ }^{1}$ Department of Entomology, The Ohio State University, 1315 Kinnear Road, Columbus, OH 43212 (Johnson. $2 @$ osu.edu).

${ }^{2}$ Division of Invertebrates, American Museum of Natural History; Agriculture and Agri-Food Canada, Research Branch, K.W. Neatby Building, Ottawa, Ontario K1A 0C6, Canada.
} 
Haliday was one of the first genera of scelionids to be described (Haliday, 1833), and the parasitism of nepid eggs was first established by Ferrière (1916) and Henriksen (1918). At least eight genera of scelionids worldwide are known to be aquatic in habits. These groups may be commonly encountered, even in North America and Europe, but little is known of their diversity or biology. In common with all groups of parasitic Hymenoptera, large parts of the world have not been well collected. As a result, we consider this paper to be a modest step in the exploration of this fascinating and unusual niche.

\section{MATERIALS}

This work is based specimens in the following collections:

AEIC D.B. Wahl: American Entomological Institute, 3005 SW 56th Ave., Gainesville, FL 32608, USA

BMNH M. Fitton: The Natural History Museum, Cromwell Road, London SW7 5BD, England

CNCI J. Huber: Canadian National Collection of Insects, Agriculture and Agri-Food Canada, K. W. Neatby Building, Ottawa K1A 0C6, Canada

MIZA J.L. García: Museo de Instituto de Zoología Agricola, Maracay, Venezuela

MZSP C.R.F. Brandão: Museu de Zoologia da Universidade de São Paulo, Avenida Nazaré 481, Bairro Ipiranga, São Paulo, SP 04263-000, Brazil

OSUC N.F. Johnson: The Ohio State University Insect Collection, 1315 Kinnear Road, Columbus, OH 43212, USA

\section{THORON HALIDAY}

Thoron Haliday, 1833: 271. Original description. Type: Thoron metallicus Haliday, by monotypy. For subsequent taxonomic literature see Johnson (1992).

Neothoron Masner, 1972: 837. Original description. Type: Neothoron lautus Masner, by monotypy and original designation. NEW SYNONYMY.

Masner (1972) proposed Neothoron and distinguished it from Thoron principally on the basis of the longer postmarginal vein in N. lautus. Later, Masner and Huggert (1979) referred to additional differences in the struc- ture of the propodeum, the armature of the dorsellum, and the position of the lateral ocelli. With a substantially greater number of both specimens and species presently before us, we find that none of the character states above serves as a distinguishing character between Neothoron and Thoron. The distance of the lateral ocellus from the inner orbit varies from less than one diameter to more than two diameters, and it principally distinguishes only $T$. metallicus Haliday. The length of the postmarginal vein intergrades from being nearly absent to being distinctly longer than the stigmal vein. Species with a long postmarginal vein may have the propodeum deeply excavate. Similarly, most species that would be classified in Neothoron have the dorsellum clearly armed. We conclude that these character states are not correlated and thus cannot justify the recognition of two genera.

We currently cannot effectively argue whether Neothoron represents a monophyletic group. The internal pattern of phylogenetic relationships in the family is poorly understood, and it is unclear which group of parasitic Hymenoptera should be considered the sister of Platygastroidea. The elongate postmarginal vein of Neothoron is commonly found among scelionids, but this cannot be construed as convincing evidence that Neothoron is paraphyletic. The best cladistic reason to synonymize the two names is that today, even with much greater sampling around the world, Thoron sensu stricto remains monobasic. Our conclusion is that Neothoron is a junior synonym of Thoron (new synonymy).

GeOGRAPHIC Distribution: Thoron is a widely distributed, but not cosomopolitan genus (fig. 1). One species, T. metallicus, is found in the eastern United States and Canada; Europe, from Ireland east to central Russia; and in northern Tunisia. A single species, T. dayi, has been collected from Indonesia. Thoron longicornis is known only from the Huachuca Mountains of southeastern Arizona. Six species are found from Panama to southeastern Brazil, and three of these are sympatric in Bolivia.

BIOLOGY: The only species of Thoron for which the biology is relatively well known is T. metallicus. This Holarctic species has 


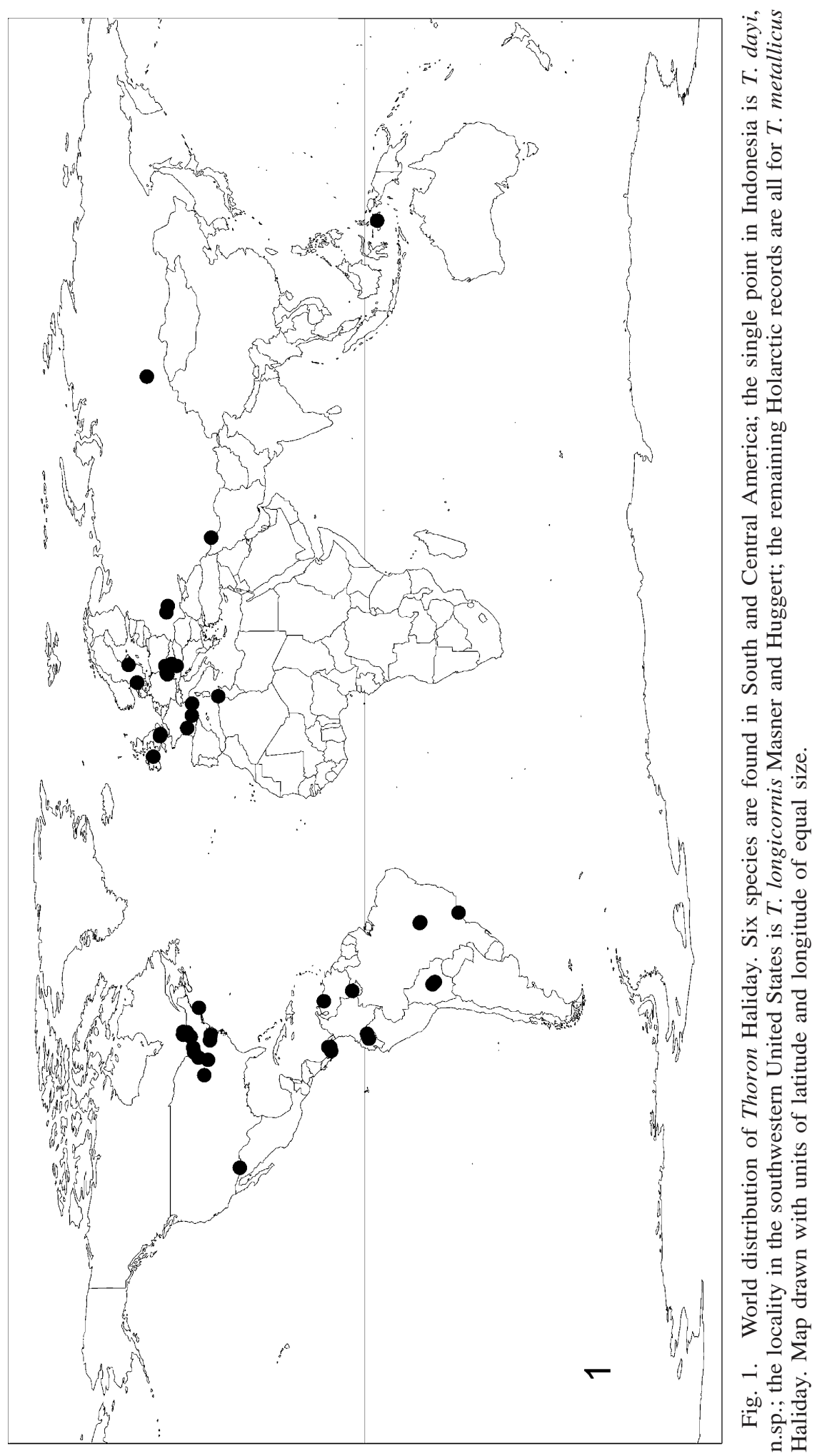


been reared from eggs of Nepa cinerea L. (Ferrière, 1916; Henriksen, 1918) in Europe. The only species of Nepa in the United States and Canada is Nepa apiculata Uhler, known from southern Québec and Ontario, west to Manitoba and North Dakota, and south to Kansas and Georgia (Sites and Polhemus, 1994). This roughly corresponds with the distribution of $T$. metallicus in the New World (fig. 1). It seems likely that N. apiculata is the host in the Nearctic, although no rearings have been made.

Thoron metallicus appears to be a univoltine species that is particularly long-lived in the adult stage. Eggs of its presumed host in the New World, Nepa apiculata, are present from mid-May to mid-June in southern Illinois (McPherson and Packauskas, 1987). Male specimens have been collected from June to September in the USA and Canada and from July to September in Europe (one male specimen from Tunisia was collected in April). In contrast, females have been collected from April to October and even as early in the year as March in Sweden $\left(59^{\circ} 31^{\prime} \mathrm{N}\right)$. We interpret these data to mean that the adult wasps emerge from the host in midsummer and that the females overwinter and then attack newly laid waterscorpion eggs the following year.

Specimens of Thoron longicornis were collected in numbers in the Huachuca Mountains of Arizona in association with nymphs and adults of Curicta pronotata Kuitert. The genus Curicta Stål, recently revised by Keffer (1996), has 16 species in the New World. Nepa does not occur in the Neotropics. We speculate that Curicta is the probable host of Neotropical Thoron because of the similarity in size and biology with Nepa.

There appear to be no records of Thoron attacking the widespread and relatively common genus Ranatra Fabricius in the Nearctic. This may well be due to a difference in oviposition habits: Nepa and Curicta generally lay their eggs in sand or mud along the shoreline, with the egg's respiratory horns protruding into the open air (McPherson and Packauskas, 1987; Keffer et al., 1994). Ranatra, in contrast, places its eggs within the tissue of aquatic vegetation, again with the respiratory horns protruding into the air (Menke, 1979).
We have only a single specimen of Thoron from the Old World outside of Europe, Russia, and the Caucasus, described here as $T$. dayi from Indonesia, yet the Nepidae are most diverse in the tropics of Africa and Asia. This leads us to predict that the Old World may yet harbor numerous undescribed species of Thoron or its close relatives.

Most of the specimens of Thoron rivalis were collected in the cerrado of central Brazil along a small permanent stream at the end of the dry season. The first rain that season fell on October 1 (1995), but specimens of both sexes of the wasp were collected in the days preceding that event.

RELATIONSHIPS: Kozlov (1970) proposed a new higher classification of the Scelionidae, dividing it into four subfamilies (Scelioninae, Teleasinae, Telenominae, and Baeinae) and 17 tribes. Of particular relevance for this discussion, Kozlov described as new the tribe Psilanteridini (six genera, Scelioninae) and the monobasic tribes Thoronini (Baeinae), Tiphodytini (Telenominae), and Pseudanteridini (Scelioninae). The monophyly of Psilanteridini was based on the explicit recognition of a single apomorphic character, the presence of a skaphion on the mesonotum. Masner (1972) correctly noted that a skaphion is present as well in the other tribes, and, further, that those three are all associated with aquatic habitats. He placed the three, together with the new genera Neothoron, $\mathrm{Mi}$ crothoron Masner, Tanaodytes Masner, and Thoronella Masner, in a single tribe, Thoronini, within the Scelioninae. Thoronidea Masner and Huggert was later described and added to the thoronine cast of characters (Masner and Huggert, 1979).

We now view the proposed monophyly of Thoronini with some skepticism. The basis for the hypothesis was primarily the structure of the female clava; the long, stiff bristles on the mesosoma; and the smooth surface of the body. Austin and Field (1997) demonstrated that one of the genera, Thoronella, possesses a complex apomorphic character complex, the Scelio-type tubular ovipositor. This strongly suggests to us that it should be removed from the Thoronini. Carlow (1992) discovered that Thoronella adults are phoretic on dragonflies. It therefore seems plausible to us that the character states used to 
define Thoronini may well be convergent and somehow associated with underwater behavior, respiration, and locomotion of the adult wasps.

There are no known species of Thoron in subsaharan Africa, none in most of tropical Asia, and none in far eastern Asia (Russian Far East, Korea, or Japan). The genus Elgonia Risbec is highly reminiscent of Thoron in both structural details and overall habitus. Species of this genus have been collected in both tropical Africa and Asia in pan traps in aquatic environments, including habitats rich in nepids. Elgonia is distinguished from Thoron by its abrupt, six-segmented female antennal clava, with all clavomeres separated; male antennal segment 5 carinate and with a small basal, ventral excavation (the sex-segment); metasomatic T3 is densely punctate; and the lower portion of the metapleuron above the hindcoxa is setose. We are continuing to investigate the question of the relationships of Thoron as a component of another, broader study, now in progress.

DESCRIPTION: Body smooth, shining, with no matte microsculpture, with scattered, long, semierect bristles, usually with underlying micropilosity; body black or, rarely, dark brown.

Head transverse, lateral ocellus separated from inner orbit by 1-2 ocellar diameters; compound eye glabrous (fig. 10); occipital carina crenulate; malar sulcus present; cheek with distinct fanlike striae; mandibles tridentate; clypeus truncate; female antenna appearing 8-segmented, radicle distinctly elongate, about one-third length of remaining A1, clava subcompact, 5-segmented, sensillar formula 1-2-2-2-1; male antenna 12-segmented, filiform, A5 not sexually modified; palpal formula 4-2.

Mesosoma about as high as wide, only slightly arched dorsally; skaphion well developed, glabrous, smooth, shining (fig. 10); notaulus varying from nearly percurrent (fig. 16) to reduced to small rudiment in anterior third of mesoscutum (fig. 15) or small furrows near transscutal articulation (figs. 17, 18); humeral and suprahumeral sulci crenulate; posterior margin of axilla deeply crenulate; scutellar disk weakly transverse, convex; dorsellum usually produced medially into subtriangular process, rarely long and pointed; propodeum variable in length, rugulose; netrion crenulate anteriorly, punctate; mesopleural carina present; mesepisternum rugulose; metepisternum narrow, usually sparsely setose; metepimeron usually glabrous, rarely densely pilose; submarginal vein in forewing closely approximated to costal margin; marginal vein short, slightly to distinctly enlarged; postmarginal vein variable in length, from rudimentary to longer than stigmal vein; basal vein nebulous, Vshaped, upper portion forming distinct acute angle with submarginal vein; submarginal vein in hindwing extremely close to costal margin, costal cell largely absent, near hamuli with narrow, short wing membrane visible.

Metasoma pedunculate, with 7 visible tergites in female, 8 in male; laterotergites well developed, deeply incised into sternites to form submarginal ridge; $\mathrm{T} 1$ elongate, in female sometimes with hump, longitudinally costate; T2 with longitudinal costae, subequal to T3 in length; T3 widest segment, always smooth, nearly glabrous; T7 in female external, subtriangular, articulating with T6 basally, not extruded with ovipositor; ovipositor internal, nontubular.

\section{KEY TO WORLD SPECIES OF THORON}

\section{Females (Unknown for $T$. spinifer)}

1. Mesoscutum and scutellum with regularly spaced, deep, thimblelike, setigerous punctures; notaulus reduced to short, isolated furrow in anterior third of mesoscutum and absent near transscutal articulation (fig. 15); Indonesia (Seram) . . T. Tayi, n.sp.

- Mesoscutum and scutellum at most with minute setigerous punctures; notaulus clearly present posteriorly near transscutal articulation, often very long (figs. 3, 16-18) ...

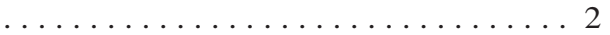

2. Apex of A1 distinctly extending above top of head (lateral view with A1 in flexed position (fig. 8) ............. 3

- Apex of A1 at same level as top of head (lateral view with $\mathrm{A} 1$ in flexed position, fig. 2)

3. Mesoscutum with only long semidecumbent bristles and no micropilosity; notaulus short, not extending anteriorly to level of posterior margin of tegula, simple, without crenulae (fig. 18); Bolivia .. T. rex, n.sp.

- Mesoscutum with both long bristles and 

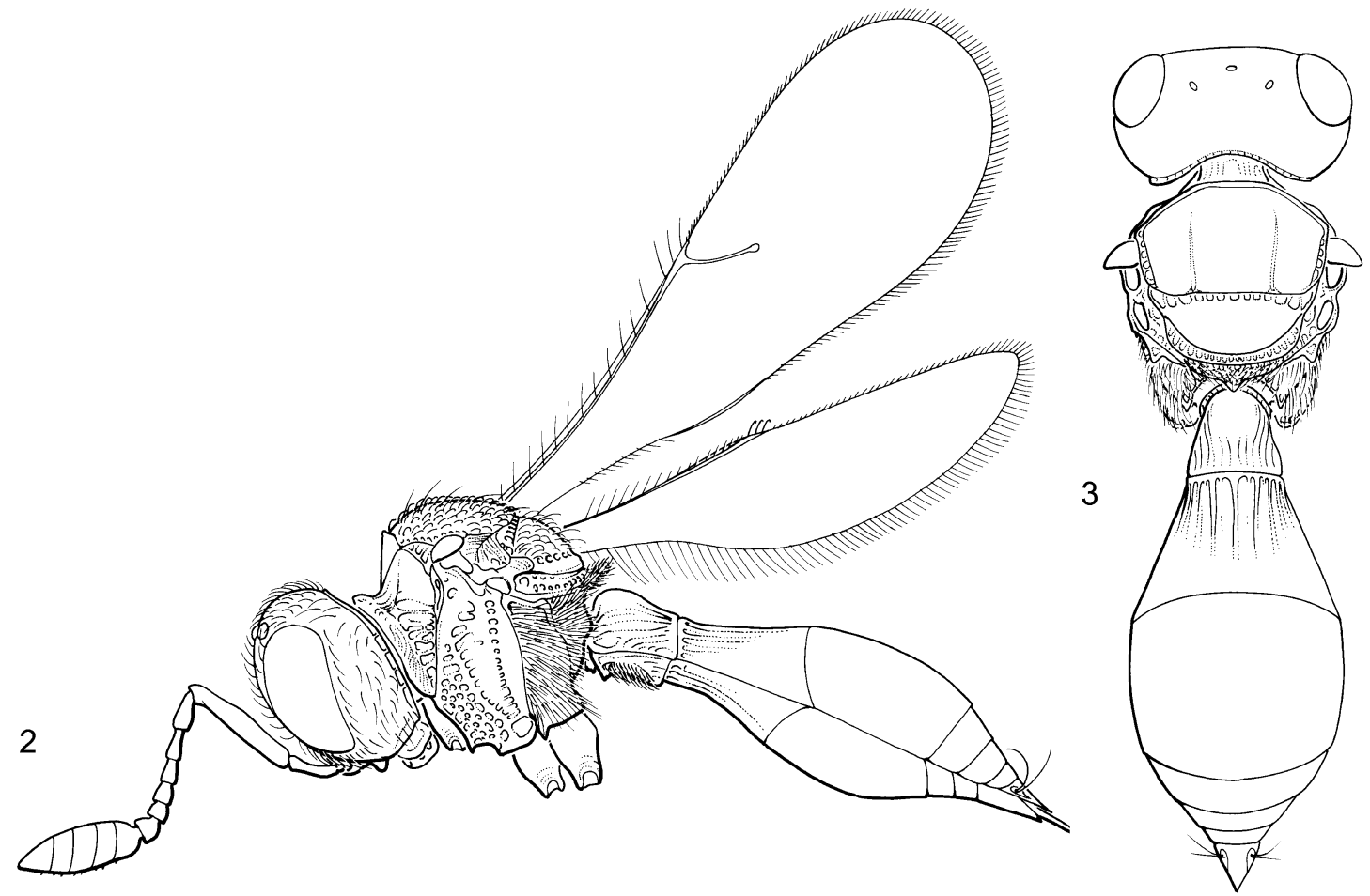

4

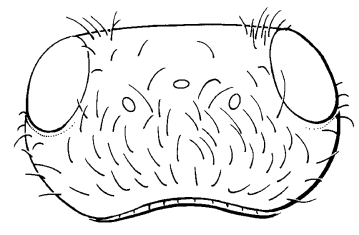

5

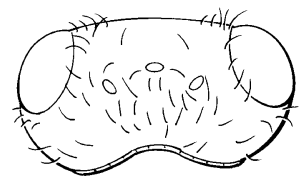

6

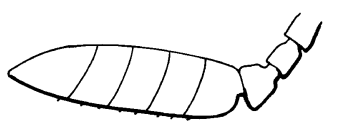

7

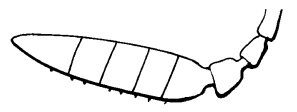

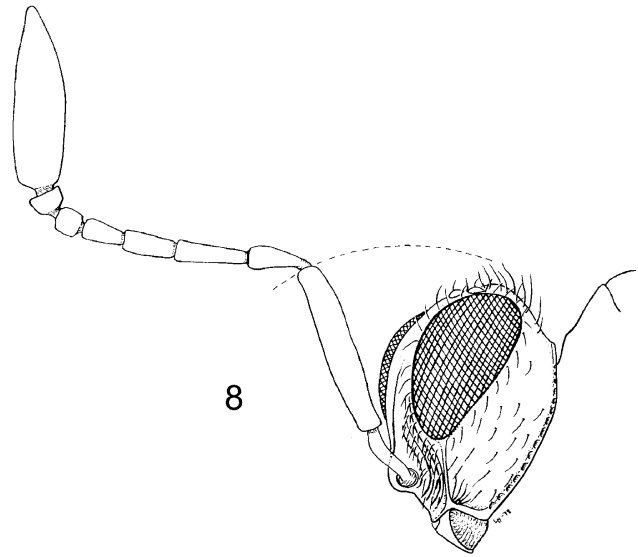

Figs. 2-8. 2, Thoron metallicus Haliday, lateral habitus; 3, T. metallicus, dorsal habitus; 4, T. metallicus, head of male with expanded genae; 5, T. metallicus, head of male with receding genae; $6, T$. rivalis, n.sp., antennal clava; 7, T. garciai, n.sp., antennal clava; 8, T. longicornis Masner and Huggert, head and antenna, lateral view (from Masner and Huggert, 1979).

shorter underlying pilosity; notaulus long, extending anteriorly beyond level of posterior margin of tegula, deeply crenulate (fig. 16); USA (Arizona) ............ ...... T. longicornis Masner and Huggert 4. Metapleuron and lateral face of propodeum uniformly covered with long, silvery hairs (figs. 2, 11); postmarginal vein extremely short or absent, much shorter than length of stigmal vein; Holarctic .......... ............ T. metallicus Haliday

- Metapleuron sparsely setose anteriorly, posterior portion of metapleuron and lateral face of propodeum nearly glabrous (figs. $12,20)$; postmarginal vein clearly developed, longer than stigmal vein ..... 5 


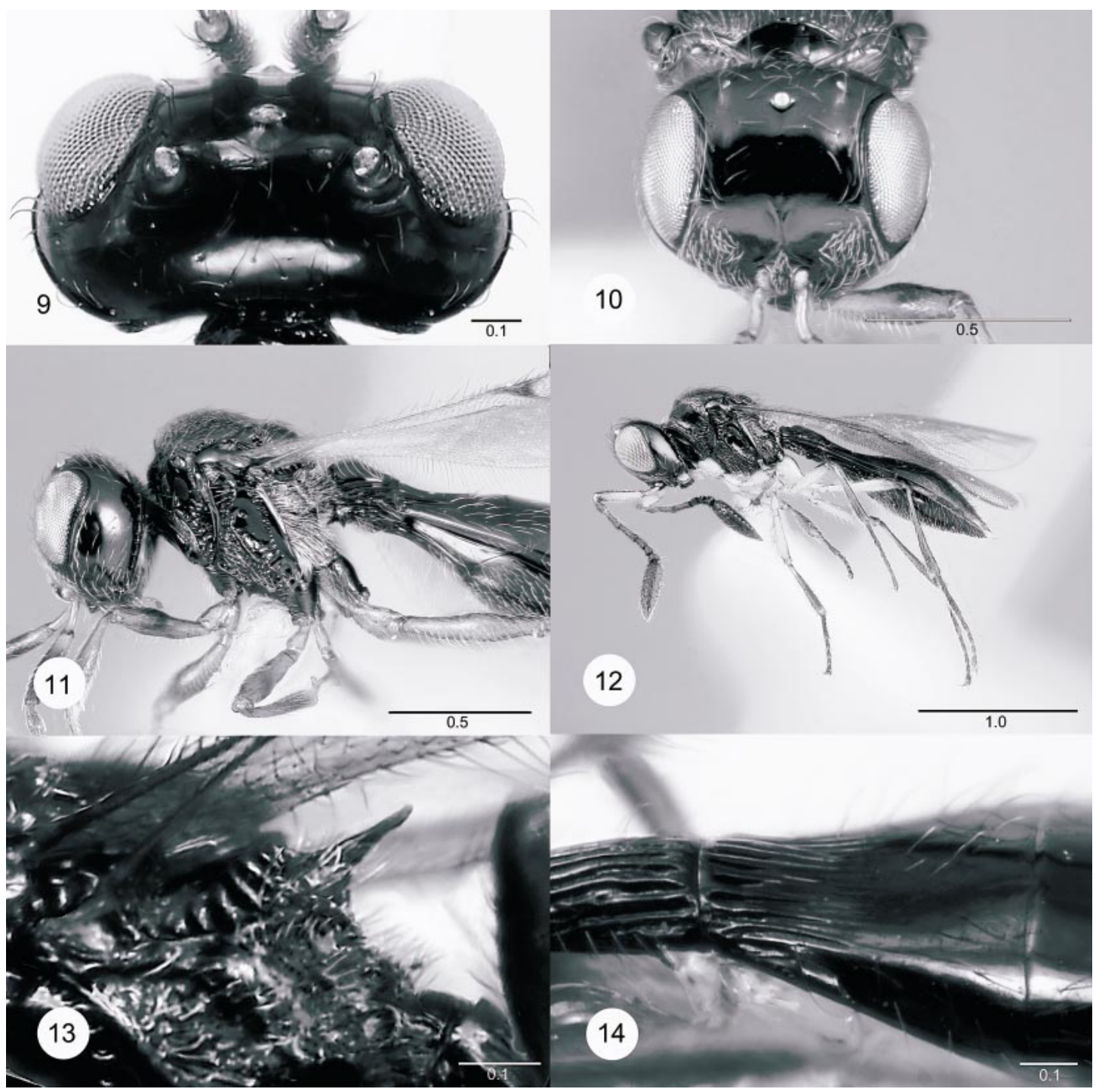

Figs. 9-14. 9, Thoron lautus (Masner), head, dorsal view; 10, T. metallicus Haliday, head, frontal view; 11, T. metallicus, female, lateral view of mesosoma and base of metasoma; 12, T. rivalis, n.sp., lateral habitus; 13, T. spinifer, n.sp., dorsellum, lateral view; 14, T. spinifer, T2, dorsolateral view. Scale bar in millimeters.

5. A2-A4 bright yellow, contrasting with dark brown A5-A7; notaulus very short, not extending anteriorly beyond level of anterior margin of tegula (fig. 17); Bolivia ... . $\ldots \ldots \ldots \ldots \ldots$. . . dux, n.sp.

- A2-A7 dark brown; notaulus long, distinctly extending beyond level of anterior margin of tegula (as in figs. 3,16$) \ldots \ldots 6$

6. T1 with strong, smooth hump (fig. 20), propodeum distinctly excavate medially; dorsellum unarmed medially (fig. 19); A4 lon- ger than A3; T3 slightly longer than wide; Bolivia, Ecuador .... T. lautus (Masner)

- T1 at most with slight convexity anteriorly, longitudinally costate; propodeum not medially excavate; dorsellum spinose medially; A4 subequal to or shorter than A3; T3 shorter than wide ........... 7

7. T2 slightly longer than T3; clava more robust, 3.5 times longer than wide (fig. 6); Brazil, Panama ........... T. rivalis, n.sp. - T2 distinctly shorter than T3; clava more 


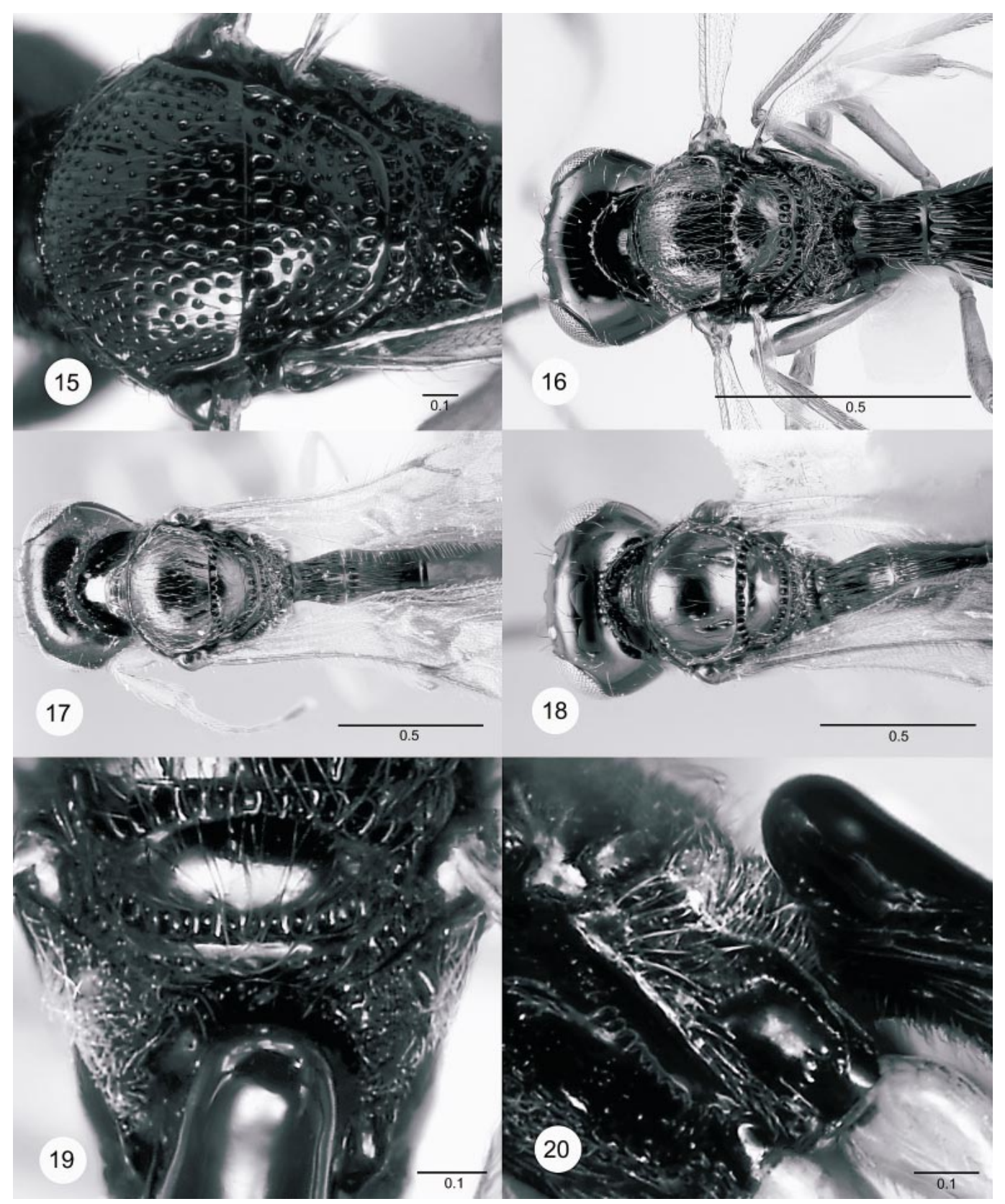

Figs. 15-20. 15, Thoron dayi, n.sp., mesosoma, dorsal view; 16, T. longicornis Masner and Huggert, head and mesosoma, dorsal view; 17, T. dux, n.sp., head and mesosoma, dorsal view; 18, T. rex, n.sp., head and mesosoma, dorsal view; 19, T. lautus (Masner), posterior mesosoma, dorsal view; 20, T. lautus (Masner), metapleuron, propodeum, and T1 horn, lateral view. Scale bar in millimeters. 
slender, 4 times longer than wide (fig. 7); Bolivia, Venezuela ..... T. garciai, n.sp.

Males (unknown for T. dayi, T. rex)

1. Notaulus very short, not extending anteriorly to level of anterior margin of tegula (fig. 17); A11 1.4 times as long as wide; Bolivia ... $\ldots \ldots \ldots \ldots \ldots \ldots$ T. dux, n.sp.

- Notaulus long, distinctly reaching or exceeding level of upper margin of tegula (figs. 3,16 ); A11 1.7-2.8 times longer than wide .... 2

2. Metapleuron above hindcoxa with dense silvery pilosity, hairs obscuring surface of sclerite (figs. 2, 11); lateral ocellus separated from inner orbit at least 2 ocellar diameters (figs. 4, 5); all coxae dark brown to black; dorsellum with small medial spine; Holarctic ............ T. metallicus Haliday

- At least posterior portion of metapleuron above hindcoxa glabrous or nearly so (figs. $12,20)$; surface smooth; lateral ocellus separated from inner orbit by one ocellar diameter or less; all coxae yellow; dorsellum variable ................ 3

3. Dorsellum produced into needlelike spine (fig. 13); costae on T2 short, reaching only to middle of tergite (fig. 14); notaulus noncrenulate, not extending anteriorly beyond anterior margin of tegula ....T. spinifer, n.sp.

- Dorsellum either unarmed or produced into wide, subtriangular spine; costae on T2 long, distinctly surpassing basal half of tergite; notauli elongate, extending anteriorly beyond notauli into anterior three-fourths of sclerite

4. Apex of A1 distinctly extending above top of head (lateral view with A1 in flexed position, fig. 8); notaulus broad, deeply crenulate (fig. 16); postmarginal vein short, not surpassing apex of stigmal vein; USA (Arizona) ...... T. longicornis Masner and Huggert

- Apex of A1 at same level as top of head (lateral view with $\mathrm{A} 1$ in flexed position, fig. 2); notaulus narrow, noncrenulate; postmarginal vein long, apex clearly extending apically beyond level of tip of stigmal vein .... . 5

5. Dorsellum unarmed; temple behind eye slight bulging in dorsal view, head as wide across temples as across compound eyes (fig. 9); Ecuador ......... T. lautus (Masner)

- Dorsellum produced into subtriangular spine; temple strongly receding in dorsal view, head widest across compound eyes .... 6

6. Hindfemur partly to entirely dark brown; T2 as long as T3; A11 2.0-2.3 times longer than wide; Brazil, Panama ..... T. rivalis, n.sp.

- Hindfemur almost entirely yellow; T2 shorter than T3; A11 2.4-2.5 times as long as wide; Bolivia, Venezuela ...... T. garciai, n.sp.

\section{Thoron dayi, new species Figure 15}

DesCRIPTION: Length $2.4 \mathrm{~mm}$. Female A4 subequal to or shorter than A3; clava robust, 3.75 times longer than wide; apex of A1 well below top of vertex; female A2-A7 dark brown; ocelli large, lateral ocellus separated from inner orbit by one-half diameter of posterior ocellus; central portion of mesoscutum and scutellum with regularly spaced, deep, thimblelike punctures (fig. 15); notaulus reduced to short, isolated furrow medially, absent near transscutal articulation, simple, without crenulae; mesoscutum with long decumbent bristles and no micropilosity; metapleuron sparsely setose anteriorly, posterior portion of metapleuron and lateral face of propodeum nearly glabrous; marginalis not thickened, as wide as submarginal or basal portion of stigmal vein; postmarginal vein extremely short or absent, much shorter than length of stigmal vein; with short spine medially; dorsal surface of propodeum excavate medially; T1 with moderately developed, smooth hump; T2 distinctly shorter than T3; T3 as long as wide.

DiAGNOSIS: Immediately distinguished from all other species of Thoron by the deeply punctate mesosoma and the notauli reduced to small furrows in the anterior portion of the mesoscutum.

ETYMOLOGY: Named after its collector, M. Day.

Material Examined: Holotype female: INDONESIA: Seram, Solea, Uncanya, viii.1987, M.C. Day, malaise trap, OSUC 77431 (BMNH).

Comments: The family Nepidae is composed of some 200 species and 12 genera around the world (Menke, 1979). This single specimen is, in our opinion, an unusual species, but one that clearly falls within the limits of the genus Thoron. Its disjunct distribution strongly suggests to us that there are more species yet to be discovered along calm watercourses in tropical Asia.

Thoron dux, new species Figure 17

DESCRIPTION: Length $1.7 \mathrm{~mm}$. Female A4 subequal to or shorter than A3; clava robust, 
3.2 times longer than wide; apex of A1 well below top of vertex; female A2-A4 bright yellow, contrasting with dark brown A5-A7; male A11 1.6-1.8 times as long as wide; ocelli large, lateral ocellus separated from inner orbit by one-half diameter of posterior ocellus; central portion of mesoscutum and scutellum at most with minute setigerous punctures (fig. 17); notaulus very short, not extending anteriorly to level of posterior margin of tegula; mesoscutum with both long bristles and shorter underlying pilosity; metapleuron sparsely setose anteriorly, posterior portion of metapleuron and lateral face of propodeum nearly glabrous; marginalis not thickened, as wide as submarginal or basal portion of stigmal vein; postmarginal vein clearly developed, longer than stigmal vein; dorsellum spinose medially, short, subtriangular; dorsal surface of propodeum not excavate; all coxae yellow; hindfemur almost entirely honey-yellow to yellow, concolorous with apex of coxa; T1 without hump, longitudinally costate throughout; costae on T2 reaching at least to posterior third of tergite; T2 distinctly shorter than T3; T3 wider than long.

Diagnosis: Similar to T. rex in the yellow color of the antennal segments $2-4$ in the female; distinguished from rex by the presence of a spine on the dorsellum.

ETyMOLOGY: From the Latin, dux, for prince or leader, and alluding to its similarity with $T$. rex.

Material Examined: Holotype female: BOLIVIA: Santa Cruz, Ichilo, "El Chore" pools, $17^{\circ} 01^{\prime} \mathrm{S}, 64^{\circ} 11^{\prime} \mathrm{W}, 253 \mathrm{~m}, 9-11 . v .1997$, L. Masner, yellow pan traps, OSUC 77426 (CNC type no. 22864). Paratypes: 1 female with same data as holotype (OSUC 77427). Santa Cruz, Andres Ibañez, Potrerillo, $17^{\circ} 40^{\prime} \mathrm{S}, 63^{\circ} 27^{\prime} \mathrm{W}, 438 \mathrm{~m}, 13-$ 16.v.1997, L. Masner, yellow pan traps, 10,1 우 (OSUC 77428, 77429).

\section{Thoron garciai, new species Figure 7}

DesCRIPTION: Length $2.0 \mathrm{~mm}$. Female A4 subequal to or shorter than A3; clava slender, at least 4 times longer than wide (fig. 7); apex of A1 at same level as top of head (lateral view with $\mathrm{A} 1$ in flexed position); female A2-A7 dark brown; male A11 2.4-2.6 times as long as wide; ocelli large, lateral ocellus separated from inner orbit by one-half diameter of posterior ocellus; central portion of mesoscutum and scutellum at most with minute setigerous punctures; notaulus long, extending anteriorly beyond level of posterior margin of tegula, simple, without crenulae; mesoscutum with both long bristles and shorter underlying pilosity; metapleuron sparsely setose anteriorly, posterior portion of metapleuron and lateral face of propodeum nearly glabrous; marginalis not thickened, as wide as submarginal or basal portion of stigmal vein; postmarginal vein clearly developed, longer than stigmal vein; dorsellum spinose medially, short, subtriangular; dorsal surface of propodeum not excavate; all coxae yellow; hindfemur almost entirely honey-yellow to yellow, concolorous with apex of coxa; T1 without hump, longitudinally costate throughout; costae on $\mathrm{T} 2$ reaching at least to posterior third of tergite; T2 distinctly shorter than T3; T3 wider than long.

Diagnosis: Most similar to $T$. rivalis (fig. 12), distinguished from it most easily by the yellow hindfemora and the more slender female antennal clava.

ETYMOLOGY: This species in named in honor of our friend and colleague, Dr. José Luis García (Maracay, Venezuela), who braved inundation and stranding in the efforts to collect the series that includes the holotype.

MATerial Examined: Holotype female: VENEZUELA: Amazonas, Surumoni, $100 \mathrm{~m}$, $3^{\circ} 10^{\prime} 30^{\prime \prime} \mathrm{N}, 65^{\circ} 40^{\prime} 30^{\prime \prime} \mathrm{W}, 13-21 . v i i .1999$, J.L. García, trampa amarilla flotante, OSUC 77474 (MIZA). Paratypes: $8 \%, 13 \delta^{\star}$ with same data as holotype (including OSUC 77475). BOLIVIA: Santa Cruz, Andres Ibañez, Potrerillo, $17^{\circ} 40^{\prime} \mathrm{S}$, $63^{\circ} 27^{\prime} \mathrm{W}, 9-11 . v .1997$, L. Masner, yellow pan trap, 1 우 (OSUC 77476).

Thoron lautus (Masner), new combination Figures 9, 19, 20

Neothoron lautus Masner, 1972: 839. Original description. Sarazin, 1986: 975 (type information).

DESCRIPTION: Length $2.4 \mathrm{~mm}$. Female A4 longer than A3; clava slender, at least 4 times longer than wide; apex of $\mathrm{A} 1$ at or below level of top of head (lateral view with $\mathrm{A} 1$ in flexed position); female A2-A7 dark brown; male A11 3.1 times as long as wide; ocelli 
large, lateral ocellus separated from inner orbit by one-half diameter of posterior ocellus; central portion of mesoscutum and scutellum at most with minute setigerous punctures; notaulus long, almost percurrent, extending anteriorly beyond level of posterior margin of tegula, simple, without crenulae; mesoscutum with both long bristles and shorter underlying pilosity; metapleuron sparsely setose anteriorly, posterior portion of metapleuron and lateral face of propodeum nearly glabrous; marginalis not thickened, as wide as submarginal or basal portion of stigmal vein; postmarginal vein clearly developed, longer than stigmal vein; dorsellum unarmed medially (fig. 19); dorsal surface of propodeum excavate medially; all coxae yellow; hindfemur partly to entirely dark brown; T1 with strong, smooth hump (figs. 19, 20); costae on $\mathrm{T} 2$ reaching at least to posterior third of tergite; T2 as long as T3; T3 slightly longer than wide.

DiAgnosis: Resembling $T$. rex in the lack of a medial spine or thorn on the dorsellum; distinguished from it by the strongly developed horn on $\mathrm{T} 1$ in the female, the shorter scape, and the presence of fine micropilosity on the mesoscutum.

Material Examined: Holotype male: ECUADOR: Napo and Coca Rivers, Napo, v.1965, 250 m, L. Peña (CNC type no. 12539). Other material: One male paratype with same data as holotype. ECUADOR: Sucumbios, Sacha Lodge, $270 \mathrm{~m}$, $0^{\circ} 30^{\prime} \mathrm{S}, 76^{\circ} 30^{\prime} \mathrm{W}, 23$.vi-3.viii.1994, P. Hibbs, malaise trap, $1 q$ (OSUC 77425). BOLIVIA: Santa Cruz, Andres Ibañez, Potrerillo, $17^{\circ} 40^{\prime} \mathrm{S}$, $63^{\circ} 27^{\prime} \mathrm{W}, 438 \mathrm{~m}, 13-16 . v .1997$, L. Masner, yellow pan traps B-17, 1 ㅇ (OSUC 77424).

\section{Thoron longicornis Masner and Huggert} Figures 8, 16

Thoron longicornis Masner and Huggert, 1979:

915. Original description. Sarazin, 1986: 975 (type information).

DESCRIPTION: Length $2.9 \mathrm{~mm}$. Female A4 distinctly shorter than A3; clava robust, 3.4 times longer than wide; apex of A1 distinctly extending above top of head (lateral view with A1 in flexed position, fig. 8); female A2-A4 reddish brown, A5-A7 brown; male A11 1.6-1.8 times as long as wide; ocelli moderately large, lateral ocellus separated from inner orbit by approximately one di- ameter of posterior ocellus; central portion of mesoscutum and scutellum at most with minute setigerous punctures; notaulus long, extending anteriorly beyond level of posterior margin of tegula, deeply crenulate (fig. 16); mesoscutum with both long bristles and shorter underlying pilosity; metapleuron sparsely setose anteriorly, posterior portion of metapleuron and lateral face of propodeum nearly glabrous; marginalis not thickened, as wide as submarginal or basal portion of stigmal vein; postmarginal vein extremely short or absent, much shorter than length of stigmal vein; with massive, strong medial spine, sharply pointed; dorsal surface of propodeum not excavate; coxae yellowish brown, with base darker than apex; hindfemur almost entirely honey-yellow to yellow, concolorous with apex of coxa; T1 without hump, longitudinally costate throughout; costae on $\mathrm{T} 2$ reaching at least to posterior third of tergite; T2 distinctly shorter than T3; T3 wider than long.

Diagnosis: This species shares with $T$. rex the elongate scape, clearly extending beyond the vertex. It differs from that species, and all other species treated here, in the deep and strongly crenulate notauli.

Material Examined: Holotype female: UNITED STATES: Arizona, Huachuca Mts., Ramsey Canyon, $25 \mathrm{~km} \mathrm{~S}$ Serra Vista, 1820 m, vi.1967, malaise trap set across creek in a narrow gully, R.F. Sternitzky (CNC type no. 15598). Other material: UNITED STATES: Arizona, Cochise Co., Huachuca Mts., Ramsey Cyn., 1820 m, 20.viii10.ix.1990, L. Masner, yellow pan traps along creek, below pool, 13 ㅇ, 55 क (including OSUC 77436, 77437).

COMMENTS: The nepid Curicta pronotata was also found in numbers in the same creek as this species and, presumably, is its host. This waterscorpion is also known from Sabina Canyon in Arizona and northwestern Mexico: these may be likely areas to find additional populations of this parasitoid.

A second species of waterscorpion, Curicta scorpio Stål, is found in Lousiana and Texas, south to Nicaragua (Keffer, 1996). This suggests that there may be another species of Thoron in that region, an area in which we have seen no specimens of Thoron.

\section{Thoron metallicus Haliday}

Figures 2-5, 10, 11

Thoron metallicus Haliday, 1833: 272. Original description, keyed. Walker, 1836: 355 (descrip- 
tion); Thomson, 1858: 420 (description); Kieffer, 1926: 171 (description, keyed); Hellén, 1971: 19 (description); Masner, 1972: 837 (synonymy); Kozlov, 1978: 622 (description); Masner and Huggert, 1979: 917 (diagnosis); Kozlov and Kononova, 1990: 322 (description).

Teleas (Thoron) metallicus: Blanchard, 1840: 290. Not seen: reference from Dalla Torre (1898b).

Thoron Metallicus: Kieffer, 1912: 104. Description.

Teleas fornicatus Nees von Esenbeck, 1834: 292. Original description. Walker, 1836: 355 (junior synonym of Thoron metallicus Haliday); Walker, 1874: 7 (figured).

Teleas solidus Nees von Esenbeck, 1834: 291. Original description. Walker, 1836: 355 (junior synonym of Thoron metallicus Haliday); Herrich-Schäffer, 1840: 58 (diagnosis);

Thoron gibbus Ruthe, 1859: 121. Original description. Kieffer, 1926: 171-172 (description, keyed); Masner, 1972: 836 (taxonomic status); Masner and Huggert, 1979: 917 (taxonomic status). NEW SYNONYMY.

Thoron Gibbus: Kieffer, 1912: 106 (description). Anteris nepea Ferrière, 1916: 71. Original description, incorrect original spelling. Masner, 1972: 837 (junior synonym of Thoron metallicus Haliday).

DESCRIPTION: Length $2.4 \mathrm{~mm}$. Female A4 subequal A3, just barely longer than A5 (fig. 2); clava robust, 2.9 times longer than wide; apex of A1 well below top of vertex; female A2-A7 dark brown; male A11 1.6-1.8 times as long as wide; ocelli small, lateral ocellus separated from inner orbit by at least slightly less than twice its diameter (figs. 4, 5); central portion of mesoscutum and scutellum at most with minute setigerous punctures; notaulus long, almost percurrent (fig. 3), extending anteriorly beyond level of posterior margin of tegula, simple, without crenulae; mesoscutum with both long bristles and shorter underlying pilosity; metapleuron and lateral face of propodeum uniformly covered with long, silvery hairs (figs. 2, 11); marginalis thickened, and surrounding membrane deeply pigmented; postmarginal vein extremely short or absent, much shorter than length of stigmal vein; dorsellum spinose medially, short, subtriangular; dorsal surface of propodeum excavate medially; all coxae dark brown to black; hindfemur light brown, lighter in color than dark coxa; T1 with strong, smooth hump, sometimes low, not strongly raised; costae on $\mathrm{T} 2$ reaching at least to posterior third of tergite; T2 distinctly shorter than T3; T3 wider than long.

DiAgNosis: Thoron metallicus is distinguished from all other species by its pilose metapleuron, the small ocelli (POL 1.5-2X OD), the short postmarginalis, and the enlarged area of pigmentation around the marginal vein.

MATERIAl EXAMINED: $660 \%, 1920$. Nearctic Region: CANADA: Québec: Gatineau Pk., Ridge Rd., 300 m, Ridge Rd., 7.viii.1982, L. Masner, 29,10 (OSUC 77496). Lac Jean-Venne, $45^{\circ} 41^{\prime} \mathrm{N}, 76^{\circ} 03^{\prime} \mathrm{W}, 20-25 . v i .1995$, yellow pan traps, sphagnum bog, 29 (OSUC 77462). Old Chelsea, 30.VI.1961, J.R. Vockeroth, 1 ㅇ (OSUC 77494). Pontiac, Ft-Coulonge, 28.X.1992, LeSage-Masner, Sift. berl. Selix [sic], 1 ㅇ (OSUC 77489). Ontario: Essex Co., Pt. Pelee National Park, wooded area by west beach, 10-23.ix.1999, O. Lonsdale, Malaise/pan traps, debu00012571, 1․ Fanshaw, 17.v.1982, A. Tomlin, 19 (OSUC 77498). Flamborough, $43^{\circ} 23^{\prime} 02^{\prime \prime} \mathrm{N}, 80^{\circ} 03^{\prime} 10^{\prime \prime} \mathrm{W}$, 20-25.vi.1995, L. Masner, yellow pan traps,

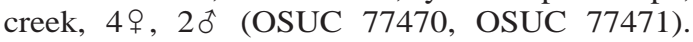
Flint Hill nr. Kemptville, 12.vi.1983, L. Dumochel, 1 ㅇ (OSUC 77497). Hess creek, $10 \mathrm{~km} \mathrm{~S}$ Kemptville, 18.vii.2001, L. Masner, yellow pan trap, 49 (OSUC 77500). London, 14.v.1982, interception trap, onion field, A. Tomlin, 19 (OSUC 77495). Mississippi Lake, 2-23.x.1991, BRC HYM TEAM, floating malaise trap, 1 ( (OSUC 77490). Mississippi Lake, McEwen's Bay, 2229.v.1991, float pan trap, L. Dumochel, 1 우 (OSUC 77499). Ottawa, 22-26.ix.1998, J.R. Vockeroth, yellow pan trap, dry Typha/Carex marsh, 1\%. Outlet Beach, Prince Edward Co., 14.viii.1968, J. R. Vockeroth, 1․ Oxford Mills, 29.v-1-vi.1973, L. Masner, 19; 12.vii.1984, 1 ㅇ (OSUC 59206); 25.vii.1979, 1 \%; 8.viii.1984, 1 क; 15.viii.1984, 2 के (OSUC 59207); 10.ix.1971, L. Masner, taken on water weeds, 10 (OSUC 77491); 13-20.vii.1973, G. Gibson, yellow pan trap, 10; 4.viii.1978, 1 के (OSUC 77492); 17.viii.1978, 1ठ; 17-24.viii.1973, 20; 27.vii.1978, 2ठ; 27.vii-3.viii.1973, 1 đ。; 2027.viii.1973, $1 \delta^{\dagger}$; 31.viii-7.ix.1973, 1 ㅇ. UNITED STATES: Indiana: Tippecanoe Co., iv.1977, J.F. MacDonald, malaise trap, $1 q$ (OSUC 77466). Maryland: Prince Georges Co., Patuxent Res. Sta., 22-26.vi.1980, pan trap, 1 (OSUC 77469). Massachusetts, Cape Cod, Eastham, 8.ix.1988, J.R. Vockeroth, pan trap, pool margin, Typha, Juncus, 2잉 $10^{t}$ (OSUC 77463-77465). Ohio: Pickaway Co., Deer Creek St. Pk., 1819.viii.2002, 21-22.viii.1999, E. Dotseth, yellow pan trap, $1 \hat{\delta}, 4$. Virginia: Clarke Co., Blandy 
Exp. Farm, 2 mi S Boyce, 23-31.v.1991, D.R. Smith, malaise trap, 29 (OSUC 77467-77468).

Palearctic Region: CZECH REPUBLIC: Celákovice, Lipovka res., 6.iv.1993, J. Macek, 3 ; ; 20.vii-3.viii.1993, J. Macek, 1 ơ (OSUC 77479); 2-6.vi.1993, malaise trap, 1 क (OSUC 77480); 219.vi.1994, malaise trap, 1 ; ; 8-16.vi.1993, pan trap, 19 . Mer. Lanzhot Ranspurk, climax hardwood forest, 9-12.viii.1991, L. Masner, pan trap, 20 ㅇ, 14 $\hat{0}$ (OSUC 77478). Lednice, 7-9.viii.1991, L. Masner, pan trap, riparian forest, 490 ㅇ, $83 \sigma^{\star}$ (OSUC 77457, 77458). Orlicke Hory, Dolni Cerna, 28.viii-12.ix.1993, J. Jezek, 24 $\widehat{\text { (OSUC }}$ 77488). Praha-Stromovka, 18-19.viii.1999, 12 ㅇ․ $180^{\circ}$ (OSUC 77459, 77460). Řevnice, env., 1012.ix.1999, L. Masner, yellow pan trap, 2 우 $10^{\text {t }}$ (OSUC 77486). Šarka, creek, 8.ix.1999, L. Masner, yellow pan trap, $6 \hat{0}$ (OSUC 77485). Slapy, env., 22.viii.1999, L. Masner, yellow pan trap, pond, $3+$, 9 $\delta$. FRANCE: Dordogne, Couze St. Front, 27.vi-11.vii.1993, H. Tussac, malaise trap, 1 ㅇ (OSUC 77441). Hérault, Montferrier sur Lez, $3^{\circ} 51^{\prime} \mathrm{E}, 43^{\circ} 40^{\prime} \mathrm{N}$, 6.vi.1994, P.G. Mason, malaise trap, 1 우 (OSUC 77481). Dép. Var, Tanneron, env., 27-29.viii.1999, L. Masner, yellow pan trap, creek, 50 우, 4 đ (OSUC 77455, 77456). HUNGARY: Közseg, 16-19.v.2001, L. Masner, yellow pan trap, sphagnum bog, $26 \%$ (OSUC 77461). IRELAND: Co. Dublin, Gollierstown, 25.vii.1945, A.W. Stelfox, 19,10 , A.W. Stelfox collecion (OSUC 77443); 3.viii.1947, 1 ô (OSUC 77445); 11.ix.1946, 1 ( (OSUC 77444). RUSSIA: Khakassia Rep., $80 \mathrm{~km} \mathrm{~N}$ Shira, $460 \mathrm{~m}, 54^{\circ} 59^{\prime} \mathrm{N}$, $89^{\circ} 32^{\prime}$ E, 26.vii.2003, J. Peck, yellow pan traps near streamside, 03-112, 40 (OSUC 74946579468). SWEDEN: Halland, Lunna, Bolg, 19.viii.1973, L. Huggert, 1 , 1 o (OSUC 77453, 77454). Västmanland, Kärrbo s:n, Solbacken, shore of Lake Mälaren, 15.iii-1.v.1989, G.E. Nilsson, malaise trap, 7 ㅇ (OSUC 43330, 43318, 43311, 43284, 43273, 43253, 43245). TUNISIA: $1 \mathrm{~km}$ S Toborka, 8.iv.1994, M. Soderlund, 1 क (OSUC 77442). UNITED KINGDOM: Buckinghamshire, Burnham Beeches, 26.viii.1984, L. Masner, screen sweeping, vegetation on sphagnum bed creek, 2 q, $30^{\text {t }}$ (OSUC 77448-77452). Oxford, 25.v.1953, J.R. Vockeroth, 1 (OSUC 77447). Oxon; Barrow Farm Fen, NCC, 18.viii14.ix.1987, malaise trap, $2 \hat{0}$ (OSUC 77482). Oxon, Woodstock, 23.x.1952, 2 ㅇ (OSUC 77484).

MAterial Cited in Literature (Kozlov and Kononova 1990; O'Connor et al., 2004; Walker, 1836): IRELAND: Down, Holywood, at the edges of ponds, among roots of aquatic plants, and on the water, A.H. Haliday. Dublin, Gollierstown, 6.x.1946, 3.xiii.1947, A.W. Stelfox; Royal Canal, Luttrellstown, 28.ix.1986, J.M. O’Connor, 1 ㅇ․ Kildare, Landenstown, 25.ix.1949, A.W. Stelfox.
UNITED KINGDOM: near London, iii- $x$, at the roots of grass, moss, \&c. Devonshire, by the edges of brooks and ponds. UKRAINE: Cherkasskaya obl., Kanyev, flood plain of Dnepr R., oak forest, 8.ii.1949, Kryshtal', 1․ Kievskaya obl., Fastov area, 11.vii.1972, S.V. Kononova, $10^{t}$. AZERBAIJAN, Lenkoran', area of Shakhagach, 22.v.1975, S.V. Kononova, 1 ㅇ․

Comments: The gena in the males are quite variable, even within the same population. Some specimens (fig. 4) have the gena subparallel or even slightly bulging so that the head is widest across the genae and not across the compound eyes. In contrast, other specimens, collected at the same time and place (e.g., in the Czech Republic), have the genae distinctly receding immediately behind the compound eyes (fig. 5). All specimens from Britain and from the Nearctic region have expanded temples. Extreme dimorphism in male morphology is known in the Scelionidae (e.g., Johnson, 1984), and this variation may be a more subtle expression of the same phenomenon.

We have not been able to locate specimens of Thoron gibbus described by Ruthe. He distinguished his species from T. metallicus based on differences in the antennal clava. In all respects, as far as we can tell from the published data, the description is consistent with T. metallicus. Ruthe's material was collected near Berlin, in moist habitats, and the species was not uncommon. Because the extensive material of Thoron from Europe consists of only a single species, we propose that Thoron gibbus is a junior synonym of $T$. metallicus (new synonymy).

\section{Thoron rex, new species Figure 18}

Description: Length $2.0 \mathrm{~mm}$. Female A4 subequal to or shorter than A3; clava robust, 2.9 times longer than wide; apex of A1 distinctly extending above top of head (lateral view with $\mathrm{A} 1$ in flexed position); female A2 brown, A3-A4 bright yellow, ocelli moderately large, lateral ocellus separated from inner orbit by approximately one diameter of posterior ocellus; contrasting with dark brown A5-A7; central portion of mesoscutum and scutellum at most with minute setigerous punctures (fig. 18); notaulus very short, not extending anteriorly to level of 
posterior margin of tegula, simple, without crenulae; mesoscutum with only long semierect bristles and no micropilosity; metapleuron sparsely setose anteriorly, posterior portion of metapleuron and lateral face of propodeum nearly glabrous; marginalis not thickened, as wide as submarginal or basal portion of stigmal vein; postmarginal vein clearly developed, longer than stigmal vein; dorsellum unarmed medially; dorsal surface of propodeum excavate medially; all coxae yellow; hindfemur almost entirely honey-yellow to yellow, concolorous with apex of coxa; T1 without hump, longitudinally costate throughout; costae on $\mathrm{T} 2$ reaching at least to posterior third of tergite; T2 distinctly shorter than T3; T3 wider than long.

Male unknown.

ETYMOLOGY: From the Latin, rex, meaning king, emphasizing its similarity with $T$. dux.

Material ExAmined: Holotype female: BOLIVIA: Santa Cruz, Andres Ibañez, Potrerillo, $17^{\circ} 40^{\prime} \mathrm{S}, 63^{\circ} 27^{\prime} \mathrm{W}, 438 \mathrm{~m}, 13-16 . v .1997$, L. Masner, yellow pan traps, OSUC 77432 (CNC type no. 22865). Paratypes: 19 with same data as holotype, OSUC 77433. Santa Cruz, Andres Ibañez, El Hondo, pools, $17^{\circ} 40^{\prime} \mathrm{S}, 63^{\circ} 27^{\prime} \mathrm{W}, 375 \mathrm{~m}, 13-$ 16.v.1997, L. Masner, yellow pan traps, 1 ㅇ (OSUC 77434); 10 with same locality data, collected 15.v.1997 (OSUC 146632). Santa Cruz, Ichilo, "El Chore" pools, $17^{\circ} 01^{\prime} \mathrm{S}, 64^{\circ} 11^{\prime} \mathrm{W}, 253$ m, 9-11.v.1997, L. Masner, yellow pan traps, 1 ㅇ (OSUC 77435).

\section{Thoron rivalis, new species} Figures 6, 12

Description: Length $2.5 \mathrm{~mm}$. Female A4 subequal to or shorter than A3; clava robust, 3.5 times longer than wide (fig. 6); apex of A1 at same level as top of head (lateral view with $\mathrm{A} 1$ in flexed position); female A2-A7 dark brown; male A11 2.0-2.3 times longer than wide; ocelli large, lateral ocellus separated from inner orbit by one-half diameter of posterior ocellus; central portion of mesoscutum and scutellum at most with minute setigerous punctures; notaulus long, extending anteriorly beyond level of posterior margin of tegula; metapleuron sparsely setose anteriorly, posterior portion of metapleuron and lateral face of propodeum nearly glabrous; marginalis not thickened, as wide as submarginal or basal portion of stigmal vein; postmarginal vein clearly developed, longer than stigmal vein; dorsellum spinose medially, short, subtriangular; dorsal surface of propodeum not excavate; all coxae yellow; hindfemur partly to entirely dark brown; T1 without hump (fig. 12), longitudinally costate throughout; costae on $\mathrm{T} 2$ reaching at least to posterior third of tergite; T2 as long as or slightly longer than T3; T3 wider than long.

Diagnosis: Most similar to T. garciai, distinguished from it by the darkened hindfemora in the male, T3 subequal to or longer than $\mathrm{T} 2$, and the more elongate female antennal clava.

ETYMOLOGY: From the Latin rivalis, meaning of a stream, referring to its association with a small permanent stream at the type locality.

Material Examined: Holotype female: BRAZIL: Goiás, Niquelândia, Serra da Mesa Survey, $14^{\circ} 01.4^{\prime} \mathrm{S}, 48^{\circ} 18.5^{\prime} \mathrm{W}, 4 . x .1995$, N.F. Johnson, yellow pan trap along small stream, OSUC 10670 (MZSP). Paratypes. 30, 39 with same data as holotype (OSUC 10460, 10516, 10619,10433 10622, 10786). Specimens with same locality, method, and collector: 27.ix.1995, 10 (OSUC 12369); 28.ix.1995, 1 ㅇ (OSUC 134089); 30.ix.1995, 20ิ, 2 우 (OSUC 335, 336, 162, 197); 1.x.1995, 2 우 (OSUC 13731, 137980); 2.x.1995, 10ิ, 3 우 (OSUC 134677, 134725, 134680, 134785); 3.x.1995, 10, 2 क (OSUC 131708, 131732, 131765); 5.x.1995, 3oิ, 2 ㅇ (OSUC 110130, 110138, 110152, 110134, 110154). Goiás, Niquelândia, $14^{\circ} 01.3^{\prime} \mathrm{S}, 48^{\circ} 18.4^{\prime} \mathrm{W}, 4-$ 5.x.1995, N.F. Johnson, malaise trap, 1 ơ (OSUC 114). Goiás, Campinaçu, Serra da Mesa survey, $13^{\circ} 52.0^{\prime} \mathrm{S}, 48^{\circ} 23.2^{\prime} \mathrm{W}, 23-25 . i i .1996$, A. Sharkov, F. Ejchel, creek yellow pan traps, 10 (OSUC 131144). Goiás, Campinaçu, Serra da Mesa survey, $13^{\circ} 52.0^{\prime} \mathrm{S}, 48^{\circ} 23.2^{\prime} \mathrm{W}, 23-25 . i i .1996$, A. Sharkov, F. Ejchel, creek yellow pan traps, 2 우 (OSUC 131350, 131296). São Paulo: Salesópolis, Estação Biológica Boracéia, Trilha dos Pilões, $23^{\circ} 39^{\prime} 07^{\prime \prime} \mathrm{S}, 45^{\circ} 53^{\prime} 48.5^{\prime \prime} \mathrm{W}, 19-22 . x .2002$, bandejas amarelas, A.P. Aguiar, J.S. Freitas, 19 (OSUC 119925). PANAMA: Colón, Quebrada López, nr. Sabanita, $120 \mathrm{~m}, \quad 9^{\circ} 19^{\prime} 19^{\prime \prime} \mathrm{N}, \quad 79^{\circ} 47^{\prime} 54^{\prime \prime} \mathrm{W}$, 16.i.2001, L. Masner, yellow pan trap, $10^{\dagger}$ (OSUC 77438). Veraguas, $1.3 \mathrm{~km} \mathrm{~S}$ Santa Fé, $300 \mathrm{~m}$, creek bed, $8^{\circ} 30^{\prime} 00^{\prime \prime} \mathrm{N}, 81^{\circ} 04^{\prime} 21^{\prime \prime} \mathrm{W}, 31 . x i i .2000-$ 3.i.2001, L. Masner, yellow pan trap, $10^{\circ}$ (OSUC 77439). Río Sajalices, $8^{\circ} 41^{\prime} 20^{\prime \prime} \mathrm{N}, 79^{\circ} 51^{\prime} 17^{\prime \prime} \mathrm{W}$, 22.i.2001, L. Masner, yellow pan trap, $1 \delta^{\dagger}$ (OSUC 77440).

COMMENTS: The only species of Curicta recorded from central Brazil by Keffer 
(1996) is C. granulosa De Carlo; this must be a prime suspect to be a host of Thoron rivalis.

\section{Thoron spinifer, new species Figures 13, 14}

DESCRIPTION: Length $2.1 \mathrm{~mm}$. Apex of A1 well below top of vertex; male A11 2.4-2.6 times as long as wide; ocelli large, lateral ocellus separated from inner orbit by onehalf diameter of posterior ocellus; central portion of mesoscutum and scutellum at most with minute setigerous punctures; notaulus moderately long, but only reaching anterior margin of tegula, simple, without crenulae; mesoscutum with both long bristles and shorter underlying pilosity; metapleuron sparsely setose anteriorly, posterior portion of metapleuron and lateral face of propodeum nearly glabrous; marginalis not thickened, as wide as submarginal or basal portion of stigmal vein; postmarginal vein clearly developed, longer than stigmal vein; dorsellum with long, slender, spinelike needle medially (fig. 13); dorsal surface of propodeum not excavate; all coxae yellow; hindfemur partly to entirely dark brown; costae on T2 short, reaching only to middle of tergite (fig. 14); T2 as long as T3; T3 wider than long.

Female unknown.

DiAGNOSIS: Distinguished from other species of Thoron by the long and acute dorsellar spine and the short costae on T2.

ETymology: From the Latin, spinifer, bearing a spine, referring to the elongate metanotal armature.

Material Examined: Holotype male: ECUADOR: Napo, Puerto Misahuallí, 250 m, 1822.ii.1983, M. Sharkey, OSUC 77477 (CNC type no. 22866).

COMMENTS: The presence of the elongate metanotal spine in the male leads us to predict that female, when discovered, is unlikely to have $\mathrm{T} 1$ expanded into a basal horn or hump.

\section{ACKNOWLEDGMENTS}

We thank C.R.F. Brandão (MZSP), J.L. García (MIZA), D.B. Wahl, M. Fitton, and J. Huber for the opportunity to study specimens of Thoron; S. Rigby and K. Bolte for illustrations; L. Musetti for assistance with data- basing and comments on the manuscript; A.P. Aguiar for collecting in Boracéia; C.R.F. Brandão and N.J. da Silva Jr. for the opportunity for NFJ to study in Goiás. This material is based upon work supported in part by the National Science Foundation under grant no. DEB-9521648.

\section{REFERENCES}

Austin, A.D., and S.A. Field. 1997. The ovipositor system of scelionid and platygastrid wasps (Hymenoptera: Platygastroidea): comparative morphology and phylogenetic implications. Invertebrate Taxonomy 11: 1-87.

Blanchard, E. 1840. Histoire naturelle des insectes. Orthoptères, Nevroptères, Hemiptères, Hyménoptères, Lépidoptères et Diptères. Paris: P. Dumenil.

Carlow, T. 1992. Thoronella sp. (Hymenoptera: Scelionidae) discovered on the thorax of an Aeschnidae (Anisoptera). Notulae Odontatologicae 3: 137-156.

Dalla Torre, C.G. de. 1898. Catalogus hymenopterorum hucusque descriptorum systematicus et synonymicus. Vol. V: Chalcididae et Proctotrupidae. Lipsiae:Sumptibus Guilelmi Engelmann, $598 \mathrm{pp}$.

Ferrière, C. 1916. Description d'un hyménoptère nouveau (Anteris nepae) parasites des oeufs de la nèpe. Archives de Zoologie Expérimentale et Générale 55: 75-80.

Haliday, A.H. 1833. An essay on the classification of the parasitic Hymenoptera of Britain, which correspond with the Ichneumones minuti of Linnaeus. Entomological Magazine 1: 259276.

Hellén, W. 1971. Die Scelioninen Finnlands (Hymenoptera: Proctotrupoidea). Fauna Fennica 23: $1-25$.

Henriksen, K.L. 1918. De europaeiske Vandsnyltehvepse og deres Biologi. (The aquatic Hymenoptera of Europe and their biology.) Entomologiske Meddelelser 12: 137-251.

Herrich-Schäffer, G.A.W. 1840. Nomenclator entomologicus. Verzeichniss der europäischen Insecten; zur Erleichterung des Tauschverkehrs mit Preisen versehen. Zweites Heft. Coleoptera, Orthoptera, Deratoptera und Hymenoptera. Regensbrug: Friedrich Pustet, 244 pp.

Johnson, N.F. 1984. Systematics of Nearctic Telenomus: classification and revisions of the podisi and phymatae species groups (Hymenoptera: Scelionidae). Bulletin of the Ohio Biological Survey 6(3). 113 pp.

Johnson, N.F. 1992. Catalog of world Proctotrupoidea excluding Platygastridae. Memoirs of 
the American Entomological Institute No. 51, 825 pp.

Keffer, S.L. 1996. Systematics of the New World waterscorpion genus Curicta Stål (Heteroptera: Nepidae). Journal of the New York Entomological Society 104(3): 117-215.

Keffer, S.L., S. Taylor, and J.E. McPherson. 1994. Laboratory rearing and description of immatures of Curicta scorpio (Heteroptera: Nepidae). Annals of the Entomological Society of America 87: 17-26.

Kieffer, J.J. 1912. Proctotrypidae (3e partie). In E. André, Species des Hyménoptères d'Europe et d'Algérie, vol. 11: 1-160.

Kieffer, J.J. 1926. Scelionidae. Das Tierreich, vol. 48. Berlin: Walter de Gruyter, 885 pp.

Kozlov, M.A. 1970. Supergeneric groupings of Proctotrupoidea (Hymenoptera). Entomologicheskoye Obozreniye 49: 203-226. [In Russian]

Kozlov, M.A. 1978. Superfamily Proctotrupoidea. In G.S. Medvedev (editor), Determination of insects of the European portion of the USSR, vol. 3, part 2: 538-664. Leningrad: Nauka, 758 pp. [In Russian]

Kozlov, M.A., and S.V. Kononova. 1990. Scelioninae of the fauna of the USSR (Hymenoptera, Scelionidae, Scelioninae). Leningrad: Nauka, $344 \mathrm{pp}$.

Masner, L. 1972. The classification and interrelationships of Thoronini (Hymenoptera: Proctotrupoidea, Scelionidae). The Canadian Entomologist 104: 833-849.

Masner, L. 1976. Revisionary notes and keys to world genera of Scelionidae (Hymenoptera: Proctotrupoidea). Memoirs of the Entomological Society of Canada 97: 1-87.

Masner, L., and L. Huggert. 1979. Descriptions of new taxa in the Thoronini (Hymenoptera, Proctotrupoidea, Scelionidae). The Canadian Entomologist 111: 911-917.
McPherson, J.E., and R.J. Packauskas. 1987. Life history and laboratory rearing of Nepa apiculata (Heteroptera: Nepidae), with descriptions of immature stages. Annals of the Entomological Society of America 80: 680-685.

Menke, A.S. 1979. The semiaquatic and aquatic Hemiptera of California (Heteroptera: Hemiptera). Bulletin of the California Insect Survey 21: 1-166.

Nees von Esenbeck, C.G. 1834. Hymenopterorum ichneumonibus affinium monographiae, genera europaea et species illustrantes. Stuttgart: J.G. Cotta, 448 pp.

O'Connor, J.P., R. Nash, D.G. Notton, and N.D.M. Fergusson. 2004. A catalogue of the Irish Platygastroidea and Proctotrupoidea (Hymenoptera). Occasional Publication of the Irish Biogeographical Society 7: 1-110.

Ruthe, J.F. 1859. A. Förster's Systematik der Proctotrupier (Hymenopt. Studien, 2. Heft) und A1. H. Haliday's Systematik der Diapriiden (Nat. Hist. Rev. 1857). Berliner Entomologische Zeitschrift 3: 118-125.

Sarazin, M.J. 1986. Primary types of Ceraphronoidea, Evanioidea, Proctotrupoidea, and Trigonaloidea (Hymenoptera) in the Canadian National Collection. The Canadian Entomologist 118: 957-989.

Sites, R.W., and J.T. Polhemus. 1994. Nepidae (Hemiptera) of the United States and Canada. Annals of the Entomological Society of America 87: 27-42.

Thomson, C.G. 1858. Sveriges Proctotruper. Tribus VII. Scelionini. Öfversigt af Kongliga Vetenskaps-Akademiens Förhandlingar 15: 417-431.

Walker, F. 1836. On the species of Teleas, \&c. Entomological Magazine 3: 341-370.

Walker, F. 1874. Notes on the Oxyura. Family 2. Scelionidae. The Entomologist 7: 4-10.

Recent issues of the Novitates may be purchased from the Museum. Lists of back issues of the Novitates and Bulletin published during the last five years are available at World Wide Web site http://library.amnh.org. Or address mail orders to: American Museum of Natural History Library, Central Park West at 79th St., New York, NY 10024. TEL: (212) 769-5545. FAX: (212) 7695009. E-MAIL: scipubs@amnh.org 